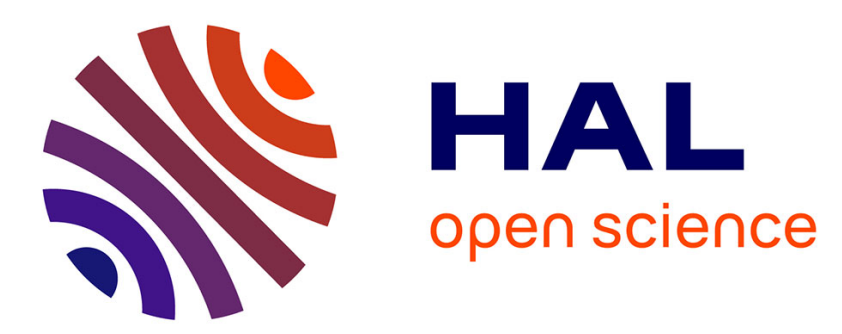

\title{
An automated system for the controlled stripping of thin silicon layers
}

\author{
R. Galloni, G. Gavina, R. Lotti, A. Piombini
}

\section{To cite this version:}

R. Galloni, G. Gavina, R. Lotti, A. Piombini. An automated system for the controlled stripping of thin silicon layers. Revue de Physique Appliquée, 1978, 13 (2), pp.81-84. 10.1051/rphysap:0197800130208100 . jpa-00244425

\section{HAL Id: jpa-00244425 https://hal.science/jpa-00244425}

Submitted on 1 Jan 1978

HAL is a multi-disciplinary open access archive for the deposit and dissemination of scientific research documents, whether they are published or not. The documents may come from teaching and research institutions in France or abroad, or from public or private research centers.
L'archive ouverte pluridisciplinaire HAL, est destinée au dépôt et à la diffusion de documents scientifiques de niveau recherche, publiés ou non, émanant des établissements d'enseignement et de recherche français ou étrangers, des laboratoires publics ou privés. 
Classification

Physics Abstracts

07.50

\title{
AN AUTOMATED SYSTEM FOR THE CONTROLLED STRIPPING OF THIN SILICON LAYERS $\left(^{*}\right)$
}

\author{
R. GALLONI, G. GAVINA, R. LOTTI and A. PIOMBINI \\ C. N. R., Laboratorio LAMEL Via de' Castagnoli, 1-40126 Bologna, Italy
}

(Reçu le 16 septembre 1977, accepté le 26 octobre 1977)

\begin{abstract}
Résumé. - On décrit un appareil automatique pour le réglage d'oxydation contrôlée de couches de silicium. Cet appareil se compose d'un ordinateur électronique et d'une cellule électrolytique qui a été projetée spécialement. L'appareil a été conçu pour être employé dans la détermination du profil de concentration d'impuretés avec la mesure de la résistivité différentielle.
\end{abstract}

\begin{abstract}
An automated apparatus, consisting of an electronic programmer and a specially designed electrolitic cell, has been set up for the controlled stripping of silicon layers. The apparatus has been planned to be used in the determination of impurity concentration profiles with the technique of differentiel resistivity measurements by layer stripping.
\end{abstract}

1. Introduction. - Carriers concentration profiles, in Ion Implanted or diffused samples, can be determined by several methods either destructive or notdestructive [1]. The method of the differential resistivity measurements by layer stripping, which we regard as the most sensitive in a wider range of dopant concentrations, suffers from the handicap of the subsequent removal of equal thickness layers from the doped surface of the samples. This stripping operation must be very accurate over a wide range of thicknesses (normally between $10^{2}-10^{3} \AA$ ), it is repetitive and therefore tedious for the operators and time wasting.

Automatic mechanical systems for the anodic stripping have already been used in conjunction with neutron activation analysis [2, 3], but a more sophisticated apparatus is required for the automatic stripping when electrical measurements (resistivity and Hall effect) have to be made.

A special cell has also been designed where the sample is mounted and left in situ till the end of the profiling. All the operations of the cycle, electrical measurements, anodic oxidation, removal of the oxide, washing and drying, are performed with the cell between the polar pieces of the magnet which gives the field for the Hall effect measurements. As already discussed in a previous paper [4], this method

(*) Work partially supported by the Commission of the European Communities under Contract no 195-76-7 ESI. is essential to keep the fluctuations in the measurements to a minimum.

2. Stripping. - The stripping technique chosen is the anodic oxidation and subsequent removal of the formed oxide. The electrolite is a solution of $90 \%$ ethylenglycol, $10 \% \mathrm{H}_{2} \mathrm{O}, 0.05 \mathrm{M} \mathrm{KNO}_{3}$ [2]. The oxide is grown at constant current density of $8 \mathrm{~mA} / \mathrm{cm}^{2}$ and the thickness of the formed oxide is controlled by the voltage generated between cathode and anode in the cell. The trend of the voltage $v s$ time of oxidation is registered for reproducibility control. A calibration curve of the thickness of silicon stripped as a function of the forming voltage is shown in figure 1 . The thickness of silicon removed has been obtained by measuring the weight variation of the samples. Ellipsometry has been used to evaluate the possible oxide thickness variations at a given forming voltage due to different resistivity of the samples. For resistivities between $10^{2}-10^{-3}$ ohm.cm the measured thickness variations were lower than $1 \%$.

3. Electronics. - The control circuit of the apparatus has been designed by considering a possible future extension of the automatism to the electrical measurement system. A sequential digital programmer has therefore been built able to perform up to 48 different functions, each with a variable time length between 1-1 $024 \mathrm{~s}$. Such a circuit (Fig. 2) contains a timer made with an oscillator and a 10 bits binary counter, a 10 bits digital comparator, a time register 


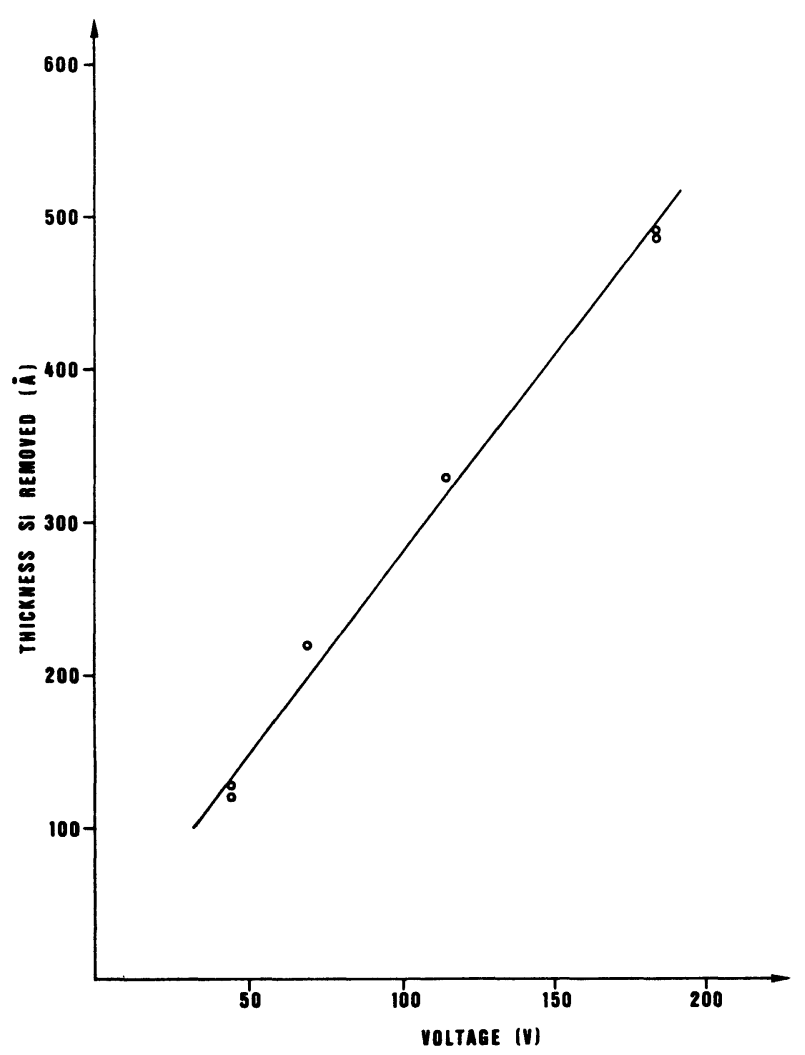

Fig. 1. - Calibration curve of the thickness of silicon stripped vs. forming voltage at constant current.

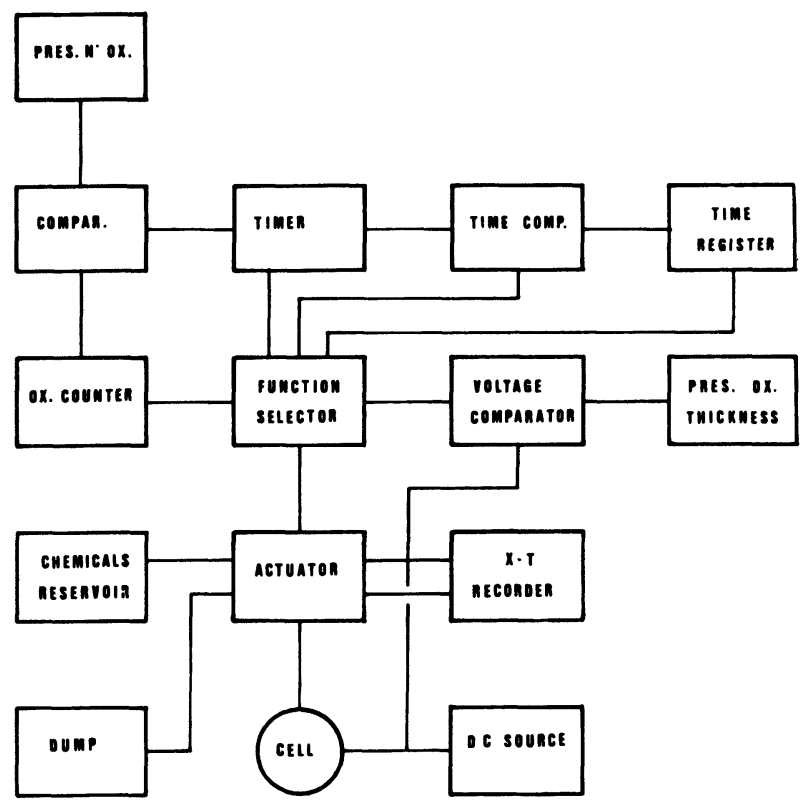

FIG. 2. - Block circuit of the electronic programmer that coordinates the operations of oxide growth, stripping, washing and drying of the sample before electrical measurements.

for the single operations made with a 48 words 10 bits programmer matrix, a function selector which coordinate the whole system : it commands the sequence of operations and it shifts the time comparator on the various registers.
At the moment the used operations are 26 and one of them is not time dependent but it is controlled by the potential difference generated between anode and cathode in the electrolitic call during the anodic oxidation. In this operation the functions selector takes into account the signal that comes from the tension comparator when there is coincidence between the anodic tension of the cell and a programmable reference tension; in this way it is possible to stop the process when the desired oxide thickness has been grown. The apparatus is also equipped with a counting system, preselection and comparation of the number of consecutive oxidations that are desired before the electrical measurement. The time required for a complete cycle of oxidation varies between 10-15 min. depending upon the oxide thickness grown.

4. Electrolitic cell. - The exploded view of the anodic cell is shown in figure 3 . Section $A$ is the sample holder with the four contacts (a) for resistivity and Hall effect measurements, the back brass contact (b) is the anode for the oxidation, (c) are the connections to the measuring instruments. Section B is the main part of the cell, it holds the agitator (d), electrolite inlet (e), inlet for all the other chemicals (f), dry nitrogen inlet $(g)$, chemicals out $(\mathrm{h})$, overfilling $(\mathrm{j})$, electrode $(\mathrm{k})$, O-ring between sections $\mathrm{B}$ and $\mathrm{C}(\mathrm{m})$.

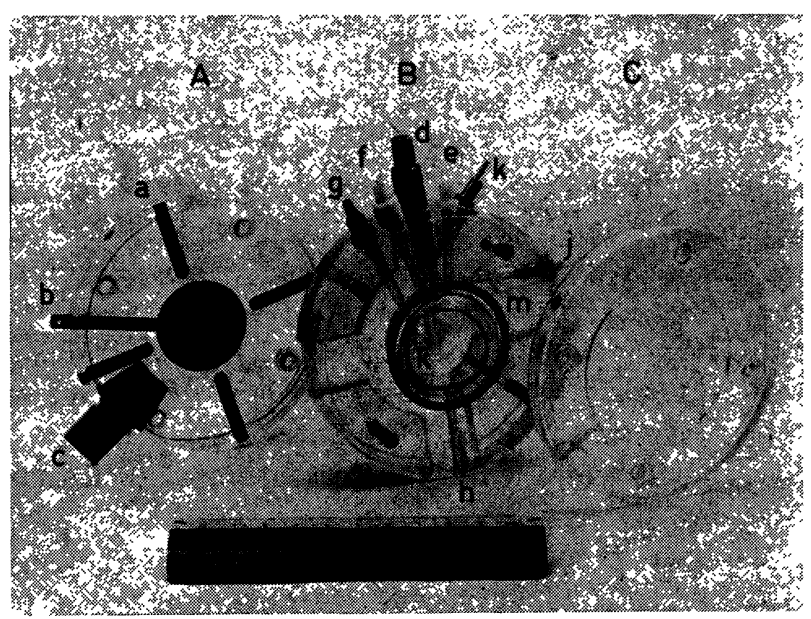

FIG. 3. - Exploded view of the anodic cell.

Section $C$ is the cell cover. To insure a perfect seal between the $\mathrm{B}$ section of the cell and the wafer to be stripped, a thin layer of Polytetrafluorethylene (teflon spray) is spread, before assembling, on the sample surface with exception to the small area $\left(0.096 \mathrm{~cm}^{2}\right)$ to be oxidized. A thin O-ring made by a silicone elastomer is then placed between the sample and the B section of the czll. The function of the teflon is to avoid small infiltrations of chemicals between O-ring and sample which would be difficult to wash away and could determine an increased leakage current. The assembled call thickness is planned to fit between the polar pieces of the magnet. 
5. Electrical measurements. - The block diagram of the apparatus used for the measurements is shown in figure 4. The DC current source used is a Keithley

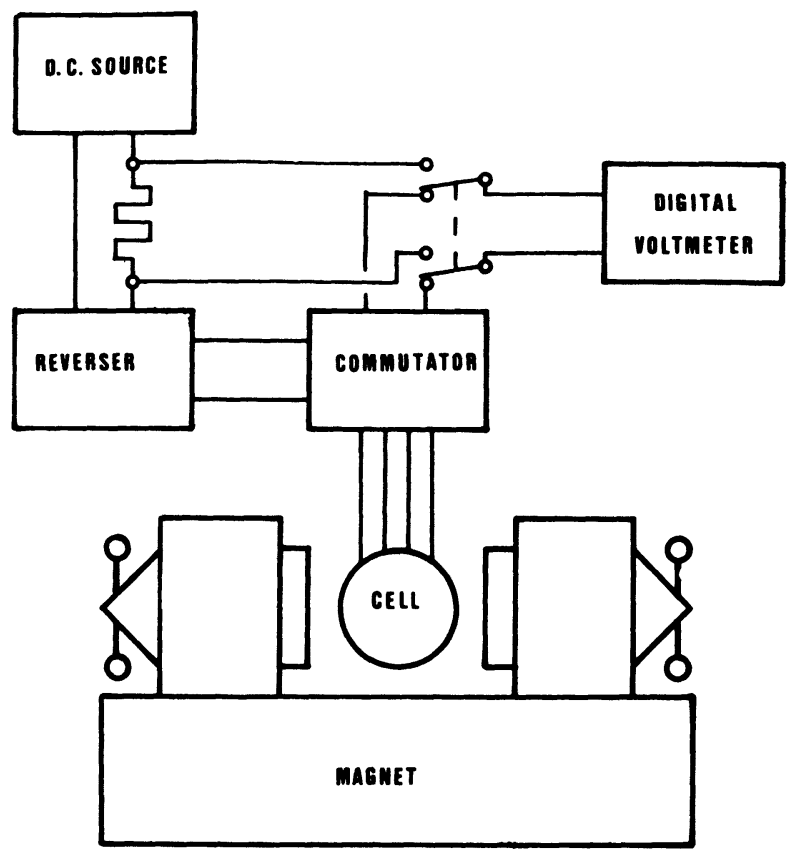

FIG. 4. - Block circuit of the complete experimental apparatus used for the determination of the doping profiles.

225 , typical currents for measuring the resistivity and Hall effect for a doping profile determination are between $10^{-3}-10^{-7} \mathrm{~A}$ depending upon dopant concentration and junction depth. An high impedance digital voltmeter (Leeds \& Northrup 2760) is used to observe the voltage on the sample. Doping profiles and mobility calculations are made by feeding directly the electrical measurements after each stripping to an Olivetti P 602 microcomputer; the following relations were used $[2,5]$ :

$$
\mu_{i}=\frac{\Delta\left(R_{\mathrm{s}} / \rho_{\mathrm{s}}^{2}\right)_{i}}{\Delta\left(1 / \rho_{\mathrm{s}}\right)_{i}} ; \quad n_{i}=\frac{\Delta\left(1 / \rho_{\mathrm{s}}\right)_{i}}{e d_{i} \mu_{i}}
$$

where $\mu_{i}, n_{i}, d$, represent carriers mobility, concentration and $i$ th layer thickness respectively ;

$$
\rho_{\mathrm{s}}=K\left(\frac{\Delta V}{I}\right)[\mathrm{ohm} /[\mathrm{C}],
$$

in our case, in which a Van der Pauw geometry was etched on the sample surface, $K=4.532$; both the temperature dependent correction coefficient and the correction factor due to imperfect geometry have been assumed $=1$. We also assumed

$$
R_{\mathrm{s}}=\frac{10^{8}}{\mathrm{~B}}\left(\frac{\Delta V}{I}\right)_{\text {Hall }}[\mathrm{ohm} / \text { gauss }] \text {. }
$$

The potential difference values were calculated by averaging over the eight possible values obtained by exchanging current and potential contacts and current direction. Figure 5 shows one of the doping

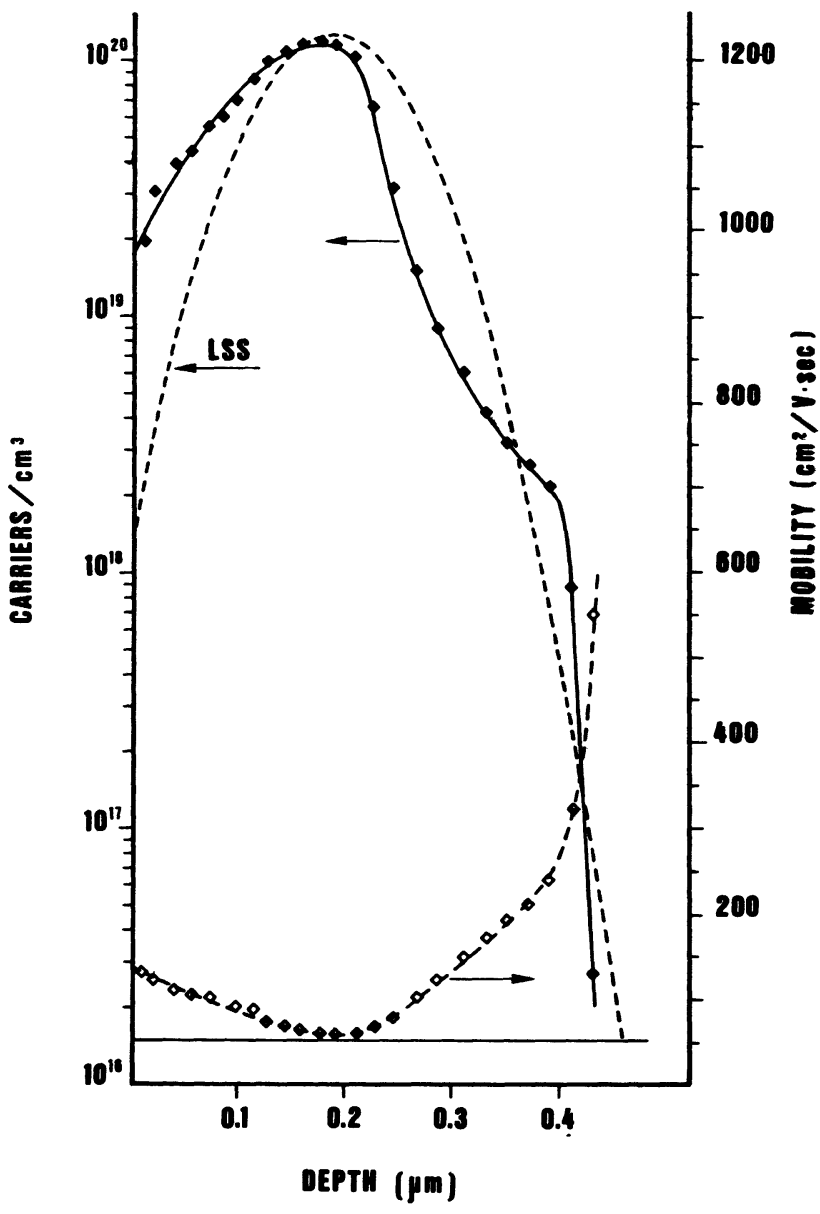

Fig. 5. - Profile of penetration of Phosphorus ions implanted at room temperature, under random conditions in silicon (100) orientation and annealed at $900{ }^{\circ} \mathrm{C}$ for $1 / 2 \mathrm{~h}$. The dotted tine is the theoretical trend obtained by the LSS theory.

profiles obtained with this experimental apparatus ; the doping was obtained by implanting, under random conditions, phosphorus ions at a dose of $2 \times 10^{15} \mathrm{at} / \mathrm{cm}^{2}$ and accelerating energy of $150 \mathrm{keV}$.

The discussion on the physical aspect of the profile is not the object of this paper, it is important to note howewer that measurements of low doping concentration and small variations in the dopant distribution are possible only if the sample is maintained in the cell with the electrical contacts fixed during all the profiling.

6. Conclusions. - The automation of the anodic oxidation for the determination of electrically active dopant distribution meets both with the requirements of saving operator time by avoiding tedious repetitive operations and of increasing the precision; casual errors observed in the hand made process due to unper fect cleaning of the sample, which produce high surface leakage currents, are infact avoided in this way.

Acknowledgments. - We wish to thank Mr. P. Ponti for his technical help in the setting up of the apparatus. 


\section{References}

[1] Dearnaley, G., Freeman, J. H., Nelson, R. S., Stephen, J., Ion implantation (North Holland pub. Co.) 1973.

[2] Cembali, F., Galloni, R., Mousty, F., Rosa, R., Zignan, F., Rad. Effects 21 (1974) 255.

[3] Restelli, G., Girardi, F., Mousty, F., Ostidich, A., Nucl. Instrum. Methods, 112 (1973) 581.
[4] Cembali, F., Galloni, R., Zignani, F., J. Phys. E : Sci Instrum., 7 (1974) 698.

[5] BUeHLer, M. G., Stanford Res. Rept. SEL-66-064, July 1966.

[6] Gibbons, J. F., Johnson, W. S., Mylroie, S. W., Projected Range Statistics 2nd. edition (1975), Dowden (Hutchinson and Ross, Inc.) 